\title{
Annual and 18-month history of retail property performance
}

Received: 1 October 2004

\section{Bryan Duncan}

has been Head of the Retail Division at Donaldsons, one of the leading independent property consultants in the UK and Europe, since November 1999. Bryan is responsible for heightening Donaldsons' retail presence, servicing key clients and schemes, and ensuring the continual contact with retailers and landlords alike. In particular, he provides expert advice on strategies for the development of and investment in shopping centres and other large scale projects. Bryan is also Chairman of Donaldsons Property Management, the 1,000-person management company servicing retail and leisure sites throughout the portfolio.

\section{Abstract}

Despite fears of a slow-down in consumer spending, the retail sector has proved more resilient over the past 18 months than many observers would have predicted. There has been a significant divergence of investment activity between property companies and private buyers. Private buyers - propped up by heavy borrowing - have focused on the yield gap between income return and interest rates as a performance benchmark. This trend has inevitably put the institutional investors at a disadvantage, effectively pricing them out of the market by their need to focus on income return and capital growth.

Shopping centres remain attractive to investors and, with plenty of recent acquisitions made by short-term investors, there is plenty of scope for further churn as buyers seek to realise their gains. There is a reasonable chance that rental growth will outpace interest rate rises over the next couple of years. This trend would continue to underpin investment activity by ensuring that any modest rise in interest rates would be offset by a rise in incomes. Clearly, the biggest short-term threat faced by the retail market is a rapid decline in consumer spending. Some form of cooling, however, is almost inevitable and could potentially impact upon the retail property markets.

\section{Keywords:}

rental value, capital value, yield, returns, interest rates, investors, shops, retail warehouses, shopping centres

Bryan Duncan

Donaldsons

48 Warwick Street

London W1B $5 \mathrm{NL}$, UK

Tel: +44 (o) 2075348543

Fax: +44 (o) 2074340045

E-mail:

bryan.duncan@donaldsons.co.uk

\section{ANNUAL PERFORMANCE SUMMARY}

\section{Rental value growth}

Centre rental values rose 4 per cent in 2003, well ahead of highstreet shops but not as strongly as out-of-town warehouses (Figure 1). Whereas strong consumer spending helped retails, all property 


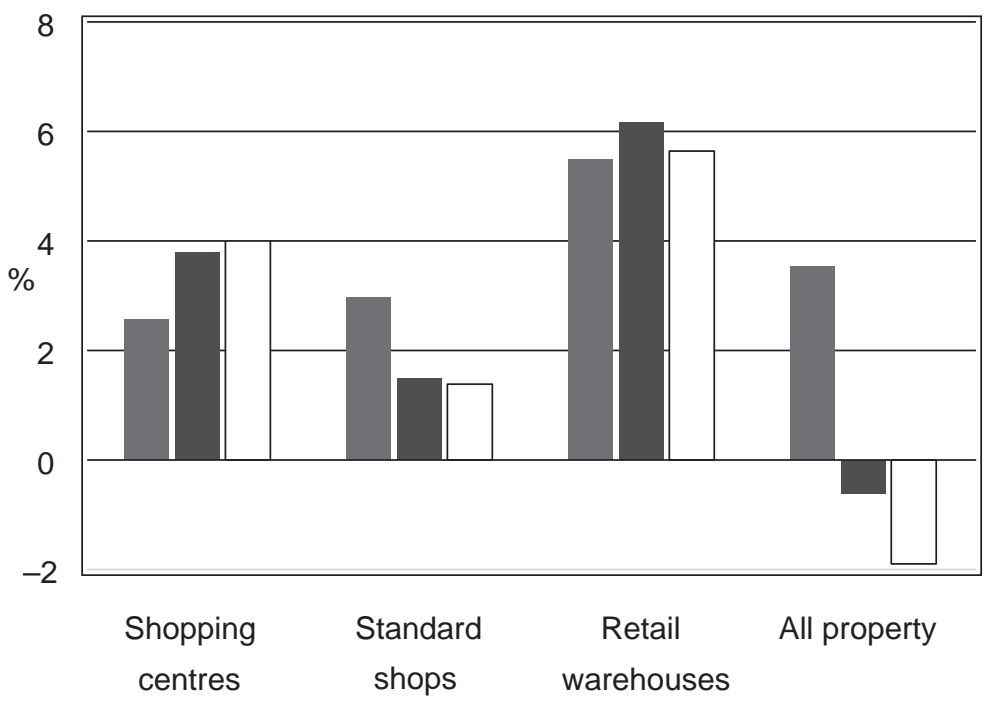

Figure 1: Rental value growth

rental values fell, marking the fragile nature of occupation markets generally.

\section{Capital value growth}

Retail warehouses showed the greatest increase, up 10.2 per cent, with average shopping centre values up 9.1 per cent. Despite much lower rental growth, shops achieved a 7.4 per cent uplift (Figure 2).

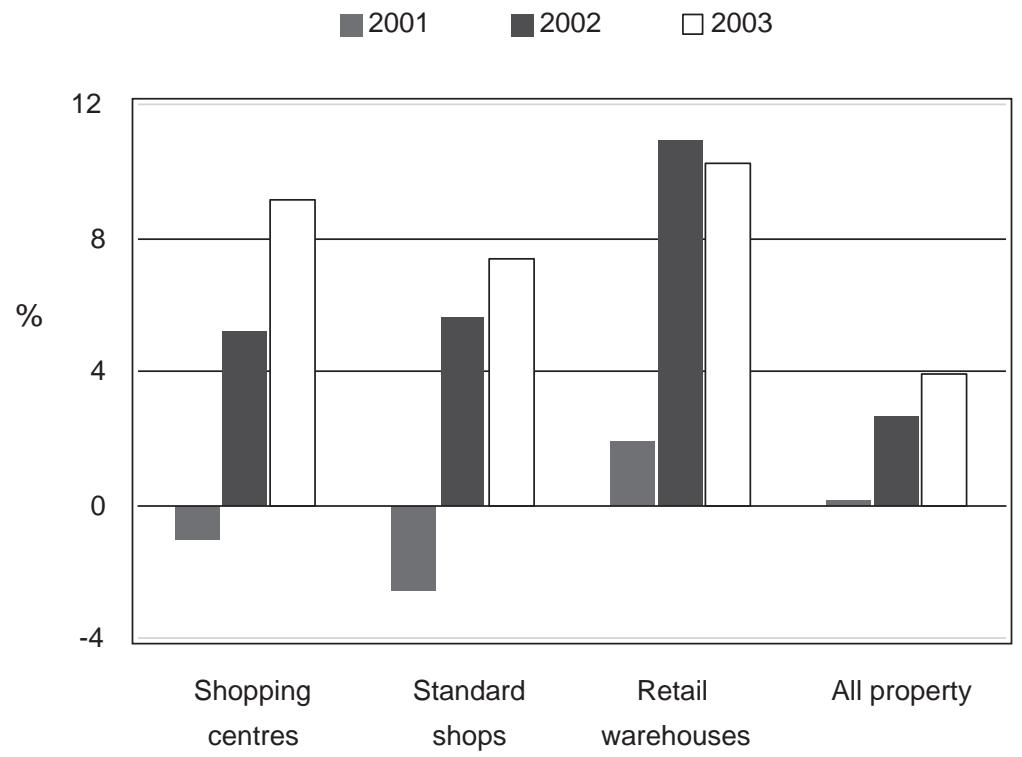

Figure 2: Capital value growth 


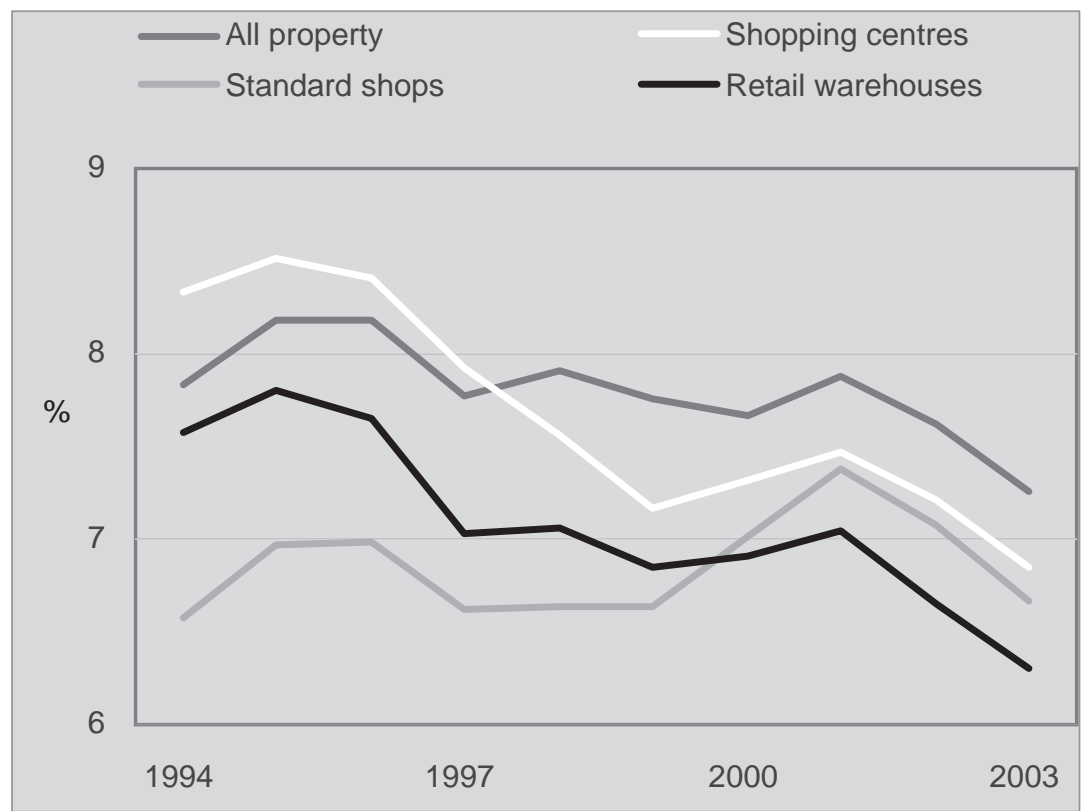

Figure 3: Equivalent yields

Capital values in 2003 were driven by external factors, and in particular the low cost of debt relative to the average 6.6 per cent income return of retails.

\section{Equivalent yields (continuous estimates)}

All property yields dropped 37 basis points (bp) in 2003, and those of centres declined at the same pace. Over the last decade, however, centres have been positively re-rated against all property, by $90 \mathrm{bp}$, and warehouses by $70 \mathrm{bp}(100 \mathrm{bp}=1$ per cent $)$. High-street shops have lost out over the last ten years, although their yields fell again in 2003 (Figure 3).

\section{Total returns}

Centres' return in 2003 of 15.7 per cent was their second highest since the rental-growth-led boom of the late 1980s. Their yields at the end of 2003 were the lowest since at least 1980. Warehouses and shops delivered respectively 16.6 per cent and 14.2 per cent total returns. All property returned 10.8 per cent in 2003 (Figure 4).

\section{EIGHTEEN-MONTH HISTORY - THE PROPERTY MARKET IN 2003}

What happened in the property investment markets in 2003 had little to do with property specifics and a very great deal to do with what happened in the wider investment marketplace.

It is interesting that the activities of the property companies and private buyers were so far removed from those of institutional funds, and that the weight of money withdrawn by the funds had no impact on pricing levels. The property market shifted away from 


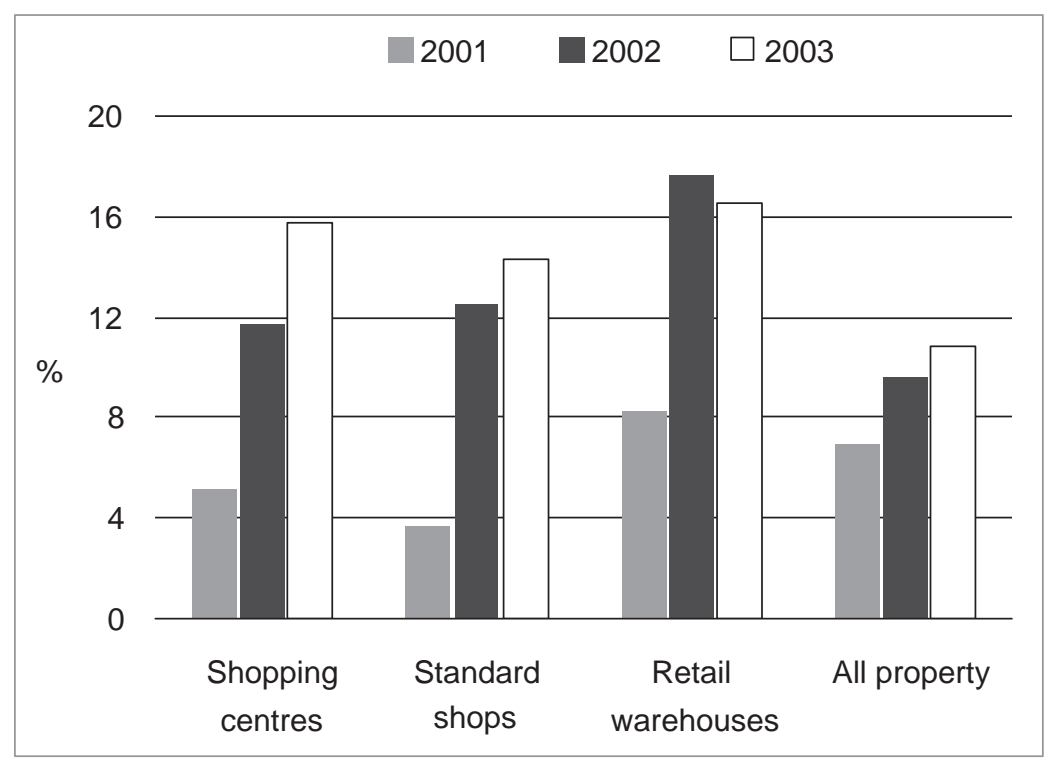

Figure 4: Total returns

its view of income return plus capital growth as the performance benchmark, a long-term total return focus, towards an emphasis on the yield gap between income return and interest rates. Capital values rose, not in response to medium-term growth prospects but under increasingly aggressive competition for potentially lowgrowth income streams capable of supporting borrowing.

It is important to consider whether this is a temporary phenomenon or a longer-term trend, because institutional investors have little or no borrowing, and are disadvantaged in a market that regularly uses gearing to produce enhanced returns. Institutions will be priced out of such a market. Figure 5 shows that in only four years out of the last 24 has income return been more than 2 per cent positive in comparison with base rates - in the last three years and in 1993. In 1993 rents were falling at 7.9 per cent per year and the effective cost of debt increased to cover that risk, thereby eroding the apparent arbitrage. This leaves 2001-2003 as the only period where arbitrage has become entrenched as a market-wide influence in a developed UK property investment marketplace.

Interest rates are frequently lower for those raising debt outside the UK, but the issue remains whether the effective yield gap will evaporate because risks rise in response to rental growth declines, or because interest rates rise. There is a reasonable chance that the next couple of years will see rental growth increasing faster than interest rates, although such growth will be tempered in its effect on income returns by review and reletting patterns. The danger that inflationary pressures will force up the costs of debt substantially is not a strong one, according to the markets.

The UK is coming slowly out of the rental recession in offices, and the industrial and retail sectors are also moving positively, so 


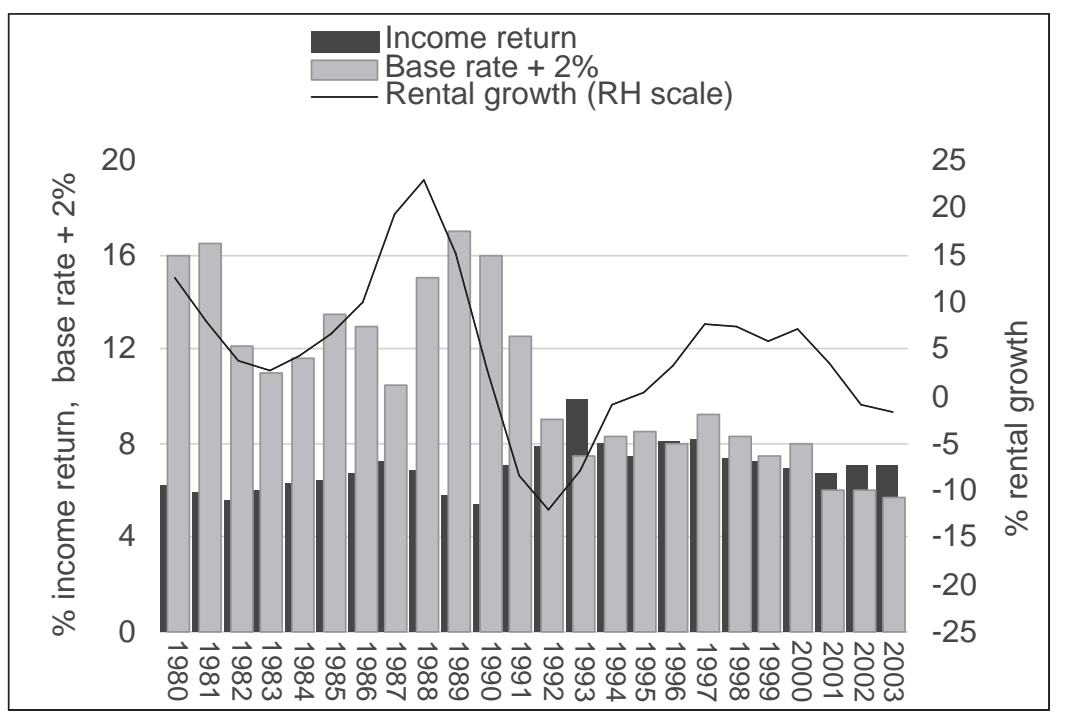

Figure 5: Arbitrage. Until recently there had been no long periods when property income return exceeded the costs of property debt, taken here as averaging 2 per cent above the base rate. Rental growth is low or negative at such moments

that a modest rise in interest payments on debt may well be offset by a rise in incomes. The arbitrage margin would prove sustainable. Unlike the rational pricing of the past, such a market does not respect total return as its benchmark because the arbitrage feature does not look to capital growth to sustain a target total return performance. Yields paid can thus be uncoupled from occupational markets, unless and until income flow itself subsides.

The broad actuarial advice currently is to increase property exposure, following its period of outperformance. To maintain their property sector weighting by buying in the market against debtbacked purchasers, institutional investors would in this scenario be forced to use gearing, and/or accept lower returns and/or seek stock that is not ideal security for bank loans, such as higher-yielding and riskier holdings.

In recent months institutional investors have begun to adjust by doing each of these things, and by using indirect investments to access investments leveraged by debt. In early 2003, however, institutional expectations were for continuing rental weakness and static yields, with the prospect of the market moving back their way. The changing assessment affected their buying stance only slowly. So, mostly, they did not compete as buyers in 2003 and their property exposure fell as they fed the market with the product it sought. Their sales exceeded their purchases by $£ 2.5 \mathrm{bn}$, the first time in over 25 years that institutional investment in property has been negative.

The fall is not explained by the switchover of funds into indirect investment, except to a minor degree. Most unit trusts and significant limited partnerships - whether based offshore or not - 
have their UK portfolios monitored by IPD. But it is only property values that are being measured, not the source of funds, and insofar as investors or vehicles gear up with debt, that debt was not and is not counted.

\section{Eighteen-month history - Retail sector overview}

The expectation at the start of 2003 - and the hope of the Monetary Policy Committee - was that the rate of growth in consumer sales would carry on slowing down, and that the rate of growth in house prices would also continue to moderate. If this occurred then low interest rates could be maintained, thus helping manufacturing pick up from a position of very obvious weakness, helping GDP growth.

To begin with this worked out and in February 2003, with housing and retail sales cooling, the base rate dropped to 3.75 per cent and in July to 3.5 per cent. But by early summer consumer spending growth was back up, and house price rises were growing in strength. By November the base rate had to be increased by 0.25 per cent, and it was raised twice more in the following six months.

Figure 6 shows that in house prices and retail spending the year ended as strongly as it began, providing a better backdrop to bustling checkouts than retailers had expected. It was certainly better than had been widely predicted. Nonetheless, traders held little pricing power, and the growth in sales values was only obtained by very keen pricing; non-food price deflation in 2003 was 1.8 per cent. There was therefore no major bonus for retailers, and hardly any upward pressure on retail rents developed in the high street.

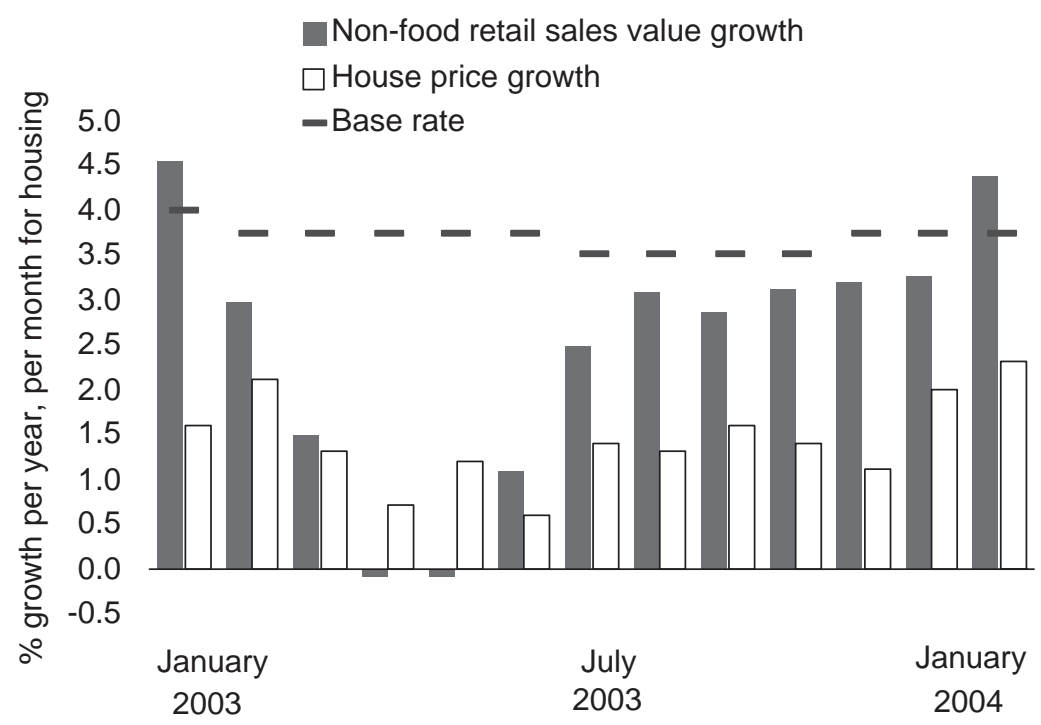

Figure 6: Spending and house prices. Initial expectations for a gradual cooling of the housing boom and a downturn in consumer spending growth were short-lived. Unfortunately retailers were not able to benefit before base rates began to rise at the year's end 
The struggle to find cost reductions to match the lower prices meant that the property element was under close scrutiny, and the favourable aspects of retail warehousing and the 'safety in numbers' of shopping centres meant they outperformed high-street shops in 2003. Of the two in-town retail types, centres invariably do better than high-street shops for rental value growth when times are tough. Figure 7 and Table 1 give the recent subsector performances. Yield impact is the capital value change resulting from any movement in yields.

\section{EIGHTEEN-MONTH HISTORY - QUARTER 12004}

Centres are undoubtedly the market segment capturing most headlines at present, and monthly and quarterly valued funds continue to increase their direct investment exposure to this class of property. Equivalent yields have been bid down very close to the lows they attained in the late 1980s' boom, on a continuous estimate basis. At 7.21 per cent at the end of March, they are 40 basis points lower than a year ago, with the impact of falling yields adding 8.5 per cent per year to capital values at the end of the first quarter.

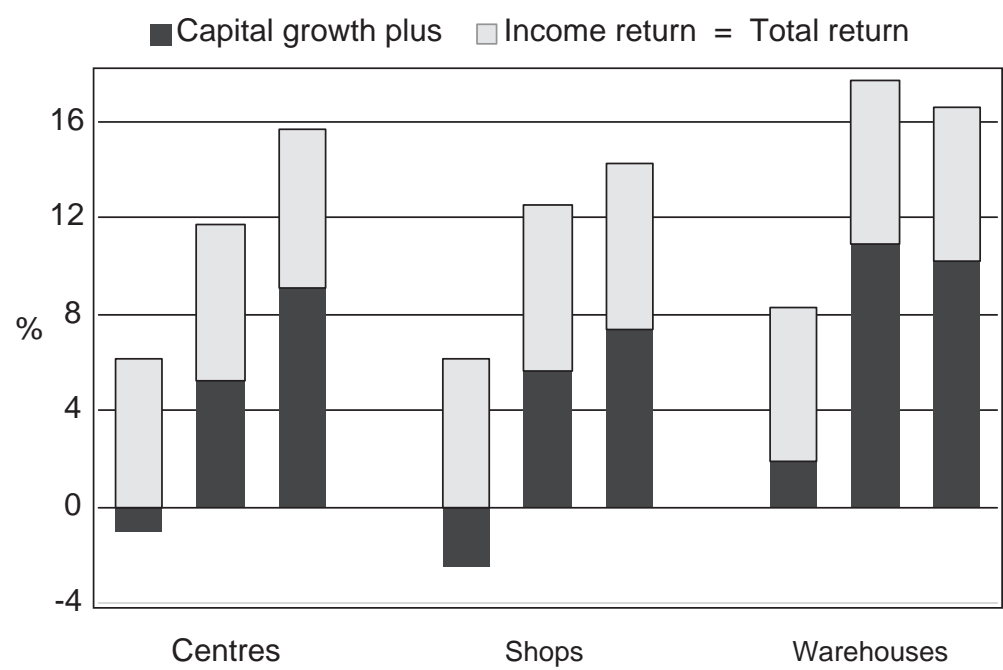

Figure 7: Investment performance. A spread of 50 basis points covers the income returns in the three retail subsectors. Their varying total return performances depend currently on capital growth. Shops, with the lowest rental growth in 2003, gained the most from yield impact

Table I: Subsector performance - Percentage in 2003

\begin{tabular}{lrrr}
\hline & Shops & Warehouses & Centres \\
\hline Rental growth & 1.4 & 5.6 & 4.0 \\
Yield impact & 6.0 & 5.6 & 5.5 \\
Capital growth & 7.4 & 10.2 & 9.1 \\
Income return & 6.9 & 6.4 & 6.6 \\
Total return & 14.2 & 16.6 & 15.7 \\
\hline
\end{tabular}


Fifteen years ago, when yields were last at this level, rental growth was running at well over 10 per cent per year, whereas today rents are increasing at 2.8 per cent per year. In fact, over the first three months of 2004 the rental growth rate of centres slipped a bit, but remains stronger than that of shops.

The impact of falling yields, aided by positive rental growth, means that the three-year-old upward trend in total returns continues. From the low point in this cycle of 4.2 per cent, total return performance has now reached up to 19.1 per cent, rivalling high-street shops (Figure 8).

The sample of centres on which this study is based is representative of the performance of small and medium-sized centres, but an approximate guide only to the performance of those over 250,000 square feet (c. $23,000 \mathrm{~m}^{2}$ ).

Figure 9 shows the degree to which shopping centre equivalent yields have been re-rated over the last three years, using continuous yield estimates. Having been virtually the same at the start of the period, centre yields are now 25 basis points lower than those of all property. Centre yields have also been positively re-rated against shop and retail warehouses over that time, by 17-20 basis points.

Figure 9 is helpful in two other respects. First, it shows that the overall yield falls in this cycle, at $50-80$ basis points in total, are not as dramatic as some reports have suggested. Secondly, recent market yield strength has not been confined to retails; in spite of negative rental growth in offices ( -3.6 per cent) and low growth in industrials ( 0.9 per cent), these sectors have also strengthened considerably.

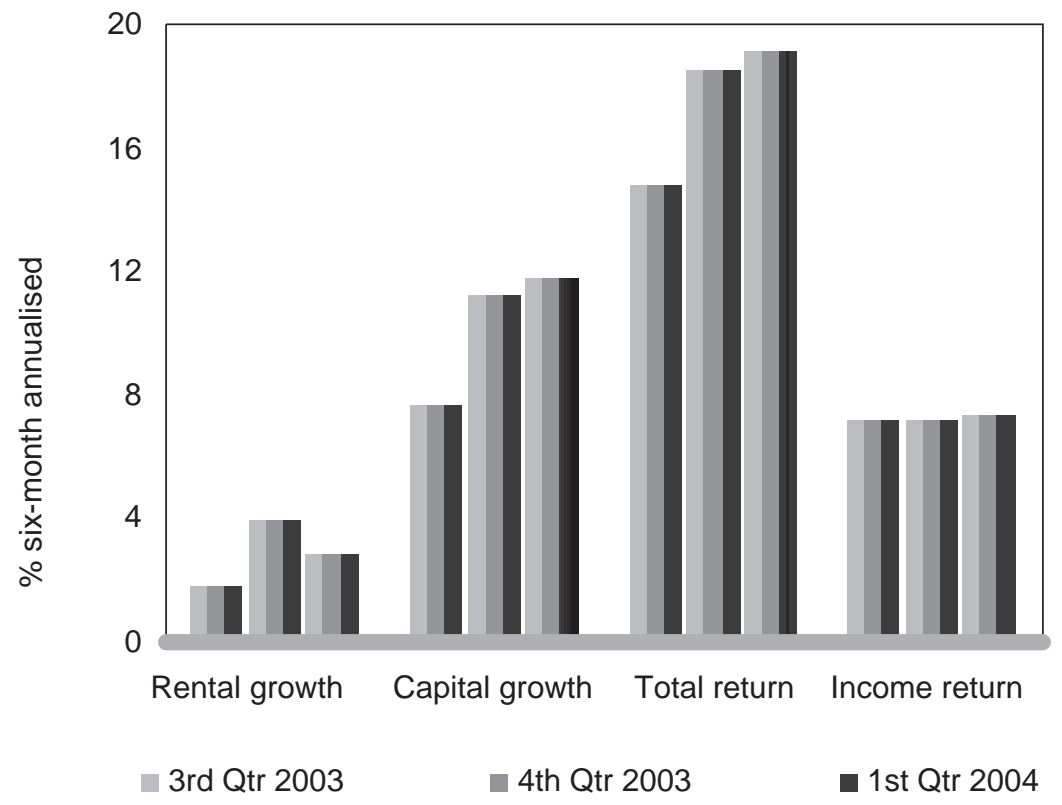

Figure 8: Centre performance 


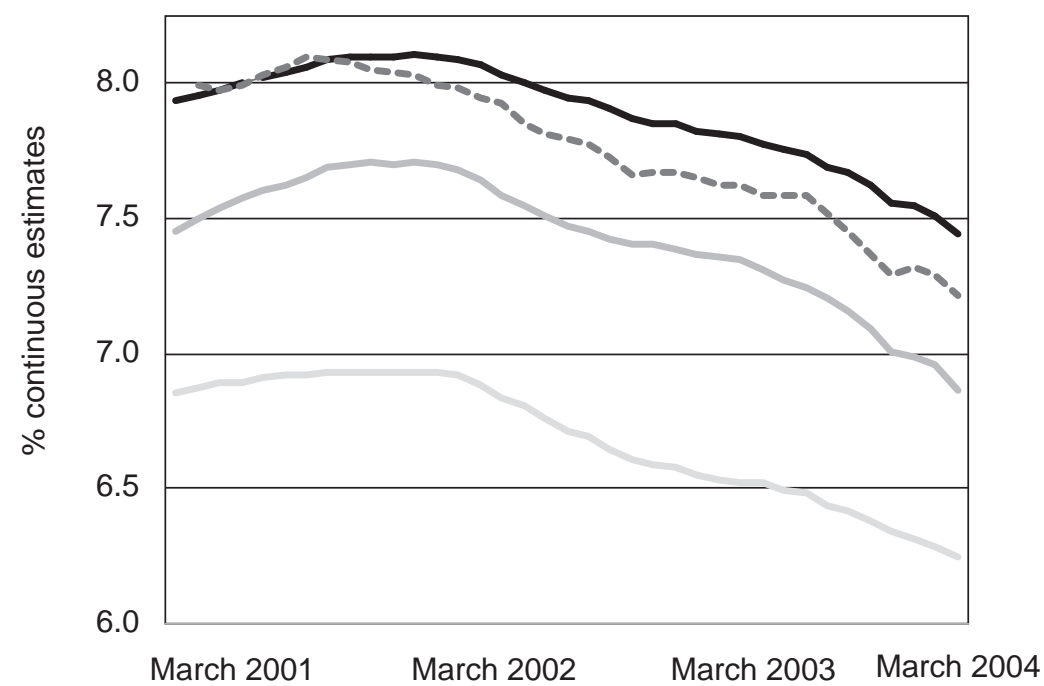

-All property ----Centres Shops Warehouses

Figure 9: Equivalent yield movements

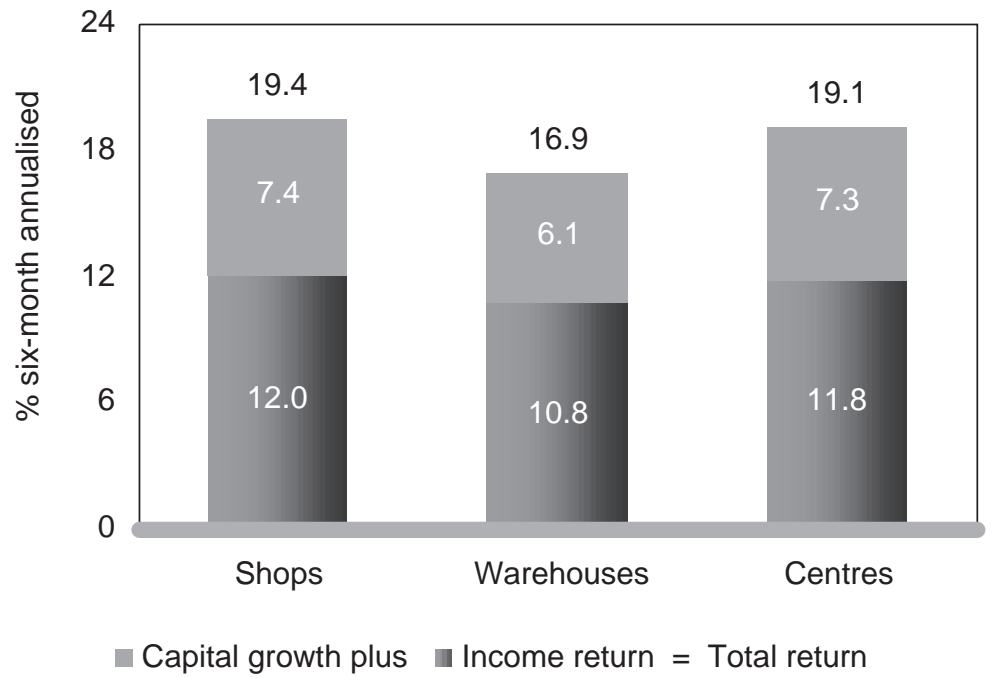

Figure 10: Sector performance summary

The investment market for centres remains strong. With plenty of the acquisitions of the past few years not made by long-term investors, the author expects turnover levels to remain high, as these buyers seek to realise gains.

While the noise greeting the Budget launch of consultation on property investment funds (PIFs) has lessened, the potential they hold for centres remains. Also helping positive sentiments are the facts that house price rises are still putting equity gains in consumers' pockets and that the market believes the change to the 


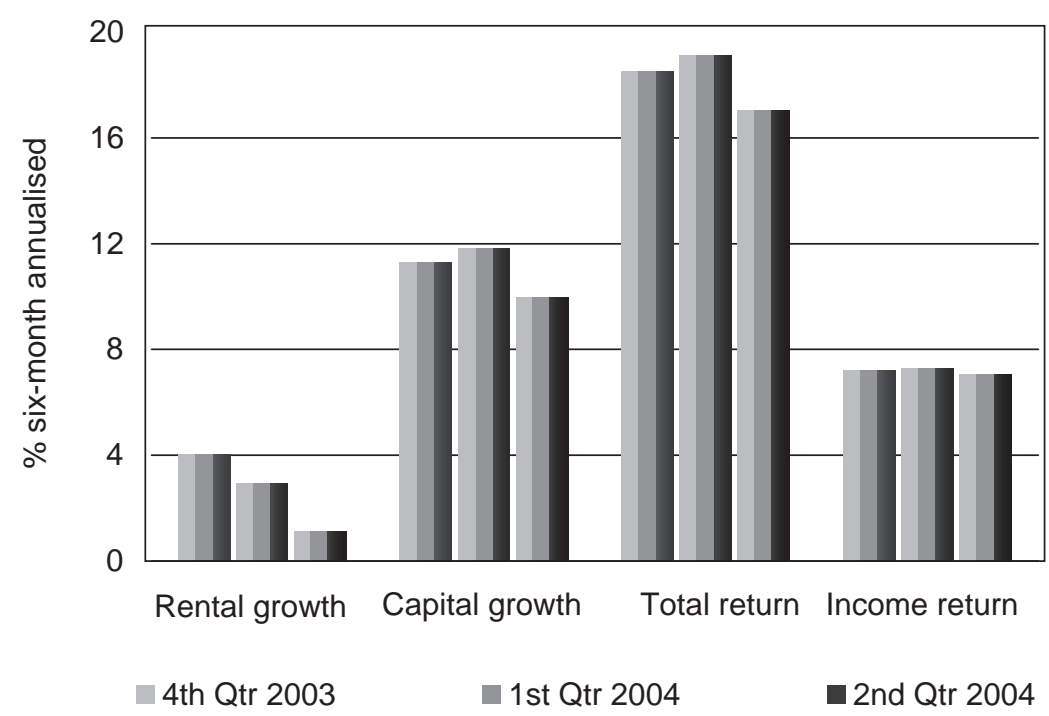

Figure 11: Centre performance

8

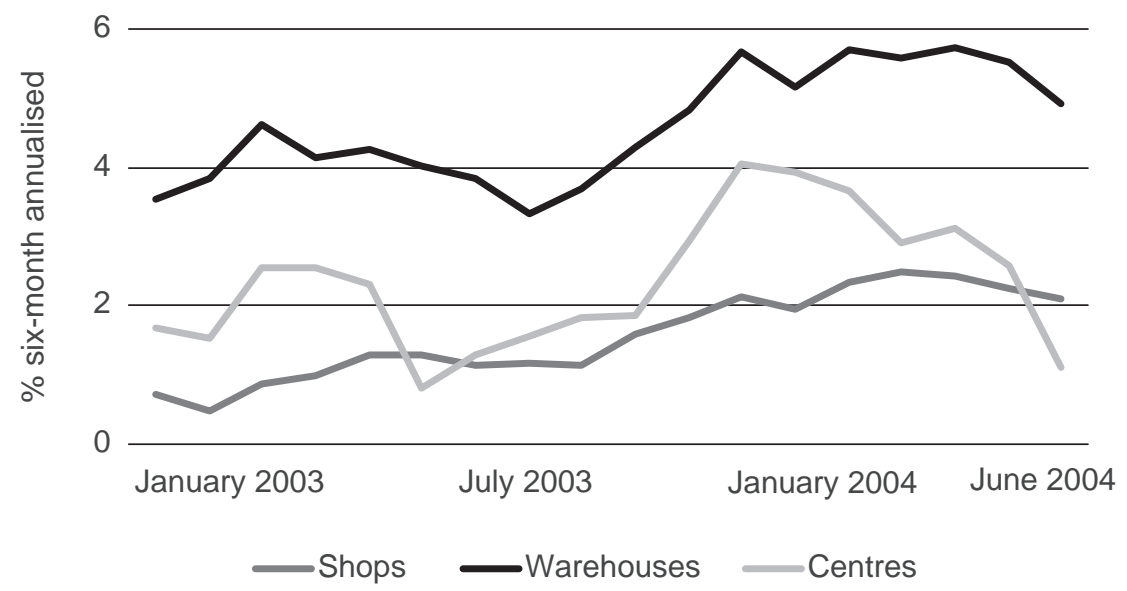

Figure 12: Retail sector rental growth

new consumer price index (CPI) inflation measure may slow or reduce interest rate rises. The negative news this quarter has been the renewed attack on upwards-only reviews by retailers and government, and heightened concerns that Dixons is just one of many retailers with unprofitable units yet to be shed.

\section{EIGHTEEN-MONTH HISTORY - QUARTER 22004}

The rental growth rate of this sample of 155 shopping centres continues to slip, and at the end of June was showing about half the rate achieved by high-street shops. Growth, at 1.1 per cent per 


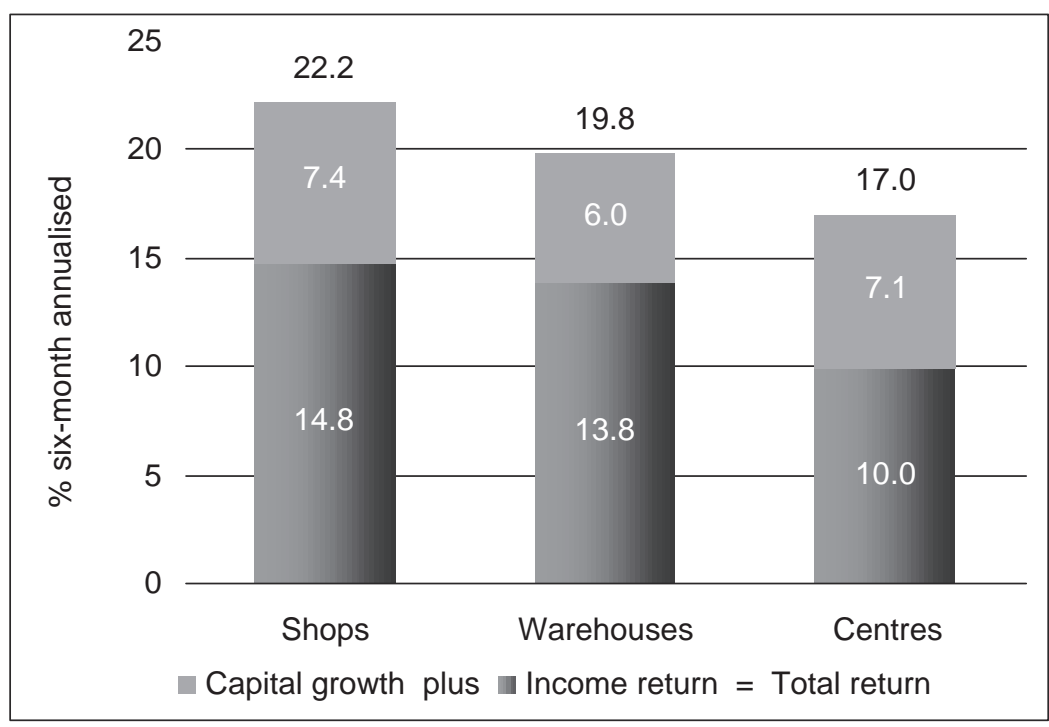

Figure 13: Sector performance summary

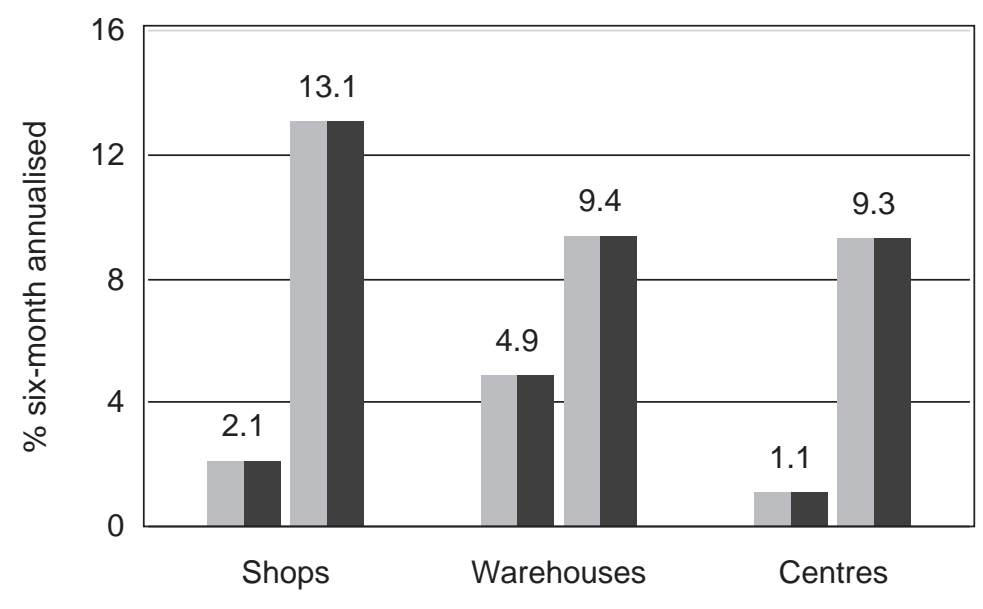

- Rental growth, \% of rental value

- Yield impact, \% of capital value

Figure 14: Performance summary

year, was close to its lowest rate for nine years. Unless this proves a temporary phenomenon, centres could well continue to underperform compared to the rest of the retail sector.

The fall in the rate of rental growth for centres was accompanied by an increase in positive yield impact, so that centre total returns at the end of June were running at 17.0 per cent, not greatly down from the 19.1 per cent at the end of the first quarter of this year (Figure 11).

As discussed for the first quarter, equivalent yields have been bid down to levels they attained in the late 1980s' rental-growth-fuelled boom, on a continuous estimate basis. At 7 per cent at the end of June, they are 52 basis points lower than a year previously. It is 
expected that potential buyers will continue to ignore the state of the occupational market.

Similarly with shops and warehouses, the pace of the decline in yields actually increased over the quarter to the end of June, boosting capital values by over 9 per cent per year. Given the level of activity in the marketplace and the number of funds, property companies and new vehicles that are currently actively seeking centre investments, there is unlikely to be any swift turnaround in the downward trend in yields. It seems unlikely, then, that there will be any serious cooling in 2004.

In spite of the one-third increase in interest rates in the past nine months, there is persistent strength in retail sales and the housing market. Policy makers, although more concerned with debt levels and inflation than with spending, publicly express a wish for a cooler climate in shops and in estate agencies. One imagines that eventually their wish will be fulfilled.

Given this as the probable outlook, it would be logical to expect a future weakening in retail occupational markets. Any downturn in retail rental growth that came beforehand would be concerning, however. There have been only brief slowdowns recently, and Figure 12 is evidence of another one occurring. Will an improving economy prevent the weakness this time round from being long term, and will oil price increases become a key factor rather than a brief shadow?

(C) Bryan Duncan 